\title{
Meeting the role of a modern geological survey: GGU's publication and data service
}

\author{
Peter R. Dawes
}

Who are we? What are our aims? What can we do? What can we do for you?

Today questions like these underlie much of the profile material presented by national and provincial geological surveys the world over. More than ever before, geological surveys are involved with self-assessment to ensure that their work areas are relevant to the needs of industry. There is increased effort to provide the geological maps and the metallogenic and hydrocarbon models that industry needs. The modern outlook is for geological surveys to encourage private-sector exploration by pin-pointing new areas with promising economic potential.

In these matters, the Geological Survey of Greenland (GGU) has been no exception, and during the past few years several initiatives have been made to improve public awareness of GGU's role and work areas, as well as to broaden the scope of actual work programmes. Of particular note is the introduction of specific services 'to facilitate the availability of relevant geological, geophysical and geochemical data to the mining industry' (Ghisler, 1990). Many of these initiatives have been described in recent issues of the Survey's Report of Activities.

Seen against this background the geoscientific database built up at GGU over many years is a vital factor in the development of mineral and hydrocarbon exploration in Greenland. This article gives a summary of the present form and scope of the Survey's publication and data service.

\section{Traditional work areas}

GGU's fundamental mission is to establish the broad geological basis for the exploration and development of Greenland's mineral resources embracing minerals, petroleum, gas, coal and hydropower (jurisdiction over hydropower resources was transferred from the Danish Government to the Greenland Home Rule Government on 1st January 1994).

Since GGU's foundation nearly 50 years ago, this has been done by a series of regional investigation and systematic mapping programmes, documentation for which is seen in the traditional survey publications (reports, bulletins and map sheets) that for many years stood as the main data base directly available to industry. Traditionally, this systematic work concerned land areas but in the last two decades the shelf and offshore regions around Greenland have become important targets for investigation and economic assessment by GGU. The reports based on marine geophysics by Denham (1974), Brett \& Zarudzki (1979) and Roksandić (1979) mark this change of direction in the early 1970 s.

Advances in science and technology are increasingly dependent on teamwork, and GGU continues its policy of cooperative ventures with close ties to universities and other geological organisations, both at home and abroad. One example of this cooperation is with our western neighbour, the Geological Survey of Canada: the two organisations have worked together for many years on geological and geophysical programmes aimed at a better understanding of the geology, structure and economic potential across our mutual boundary. This cooperation has resulted in publications in international journals as well as individual monographs. The most recent monograph is a volume in the Decade of North American Geology project (Trettin, 1991) - a comprehensive description of the Innuitian orogen and arctic platform, which are the major lithotectonic provinces extending across northern Canada and into North Greenland.

\section{Resource characterisation joins geological mapping}

GGU's present research programmes and those planned for the immediate future are characterised by increased emphasis on applied and economic geology. Examples of this are the hydrocarbon-geological activities now being undertaken (Stemmerik et al., 1990) and the long-term metallogenic programme aimed at assessment of Precambrian supracrustal belts with respect to primary environments and tectonic regimes (Dawes \& Schønwandt, 1992). Determination of primary geological setting is a major step in any mineral resource evaluation. Resource characterisation has now joined geological mapping as a key activity at GGU. Thus, as well as the traditional role of acquiring new knowledge of Greenland's geology and systematically compiling this and presenting it in standard 


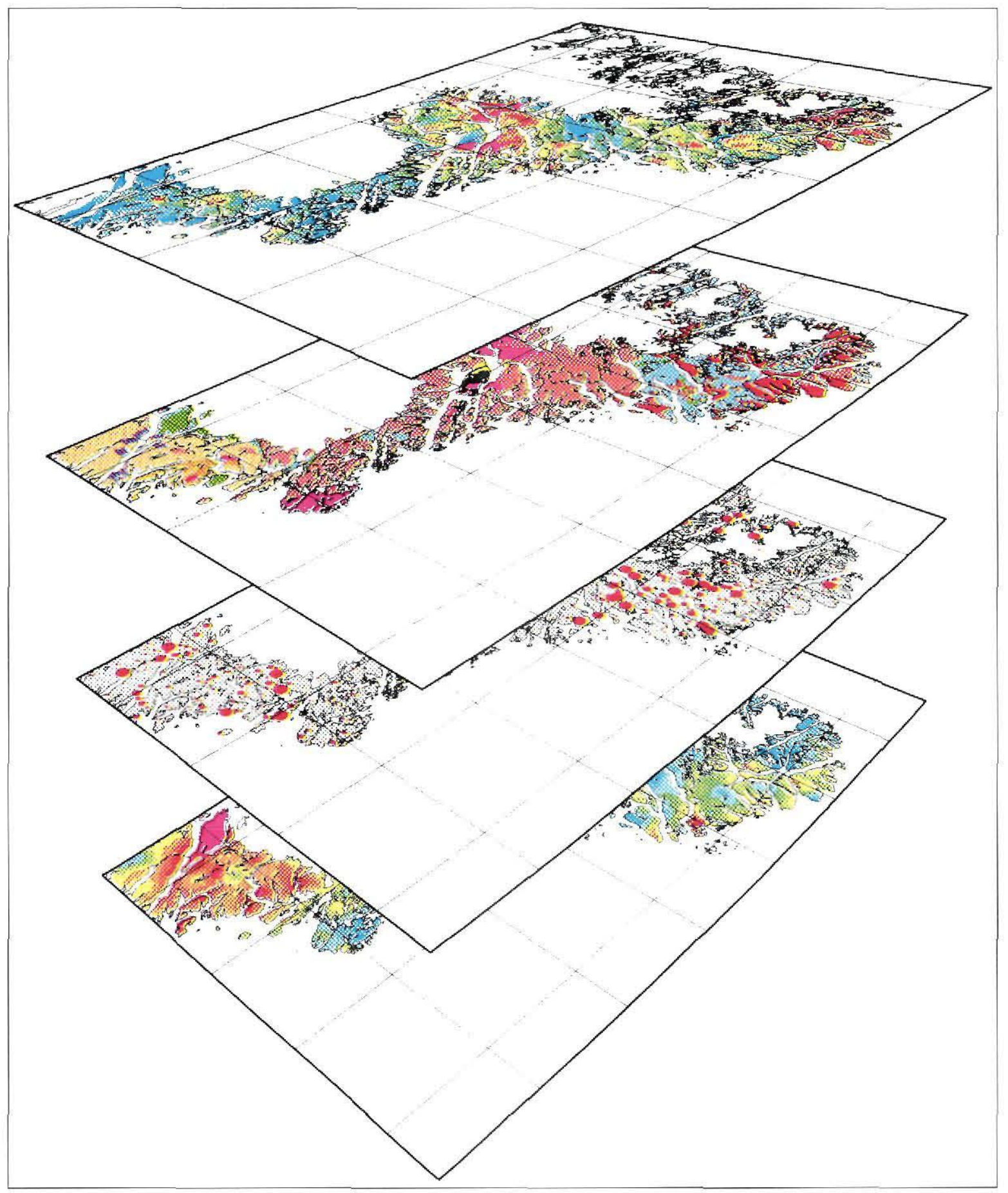

Fig. 1. GGU's Thematic Map Series launched in 1990 brings together different types of geoscientific data. Shown here are four sheets from South Greenland (Thorning et al., in press). 
maps, recent emphasis has been to refine processing and cataloguing techniques, and to store and present data in a form that can be readily disseminated to the mining and petroleum industries. This approach is exemplified by, for example, the recently introduced Thematic Map Series (Fig. 1) and the 'Offshore West Greenland - Exploration Information' package. The underlying concept of these products is to bring together different types of geoscientific information for large regions to provide a single, all-embracing data set to facilitate an understanding of Greenland's geological provinces and their economic potential (see later).

The progress in acquisition and processing technology seen internationally in the past decade determines that an increasing amount of geoscientific data is available at GGU in digital form. Such data are fundamental to the Survey's own research programmes as well as being available for direct commercial application. This provision of selective digital data sets increases cooperation with industry, meeting specific requirements of resource evaluation based on numerical modelling.

\section{Publications, data and services}

The geoscientific database and expertise on Greenland available at GGU is based on primary data collected by the Survey and other geological expeditionary activities in Greenland, as well as data resulting from industry exploration. GGU is the depository for the geoscientific results of all commercial exploration in Greenland and its offshore regions. Confidentiality clauses on industrial data determine when these data can be released to the public.

The material and services listed in the following are available for study or purchase at GGU's headquarters in Copenhagen. In Greenland a set of GGU publications is available for consultation at the Home Rule Government offices (Erhvervsdirektoratet, or Trade and Industry office) in the capital Nuuk. The latest addition to the database in Nuuk is a microfiche file of released mining company reports (see below under 'Industry report library').

Specifications of all material published by GGU are contained in the freely available List of Publications that contains a topic index that among others has sections on 'Prospecting', 'Mineralisation', 'Onshore geophysics', 'Offshore geophysics, 'Sedimentary and petroleum geology' and 'Glaciology and hydro-power'. A booklet on geodata has been issued as part of the series Trade and Industry in Greenland (Grønlands Baseselskab, 1991) and this also contains information on GGU's unpublished data base and services.

GGU's publication sales office in Copenhagen is open during normal working hours, but for many of the data services listed below prior contact with the Survey is recommended.

Greenland geoscientific data are reviewed here under five headings:

- Publications

- Digital data

- Newsletters, unpublished reports and maps

- Rock sample archives

- Bibliographical and special services

\section{Publications}

Listed here are GGU's main scientific series that are published in English. Selected papers on GGU's work published in international periodicals and symposia volumes formed Miscellaneous Papers 1-427; a reprint series discontinued in 1989. During the past five years between 25 and 55 articles per year have been published in international scientific journals as a consequence of GGU research.

\section{Bulletins and Reports}

These two publication series, now numbering together 330 issues, provide reviewed accounts of all aspects of Greenland geology. Recent numbers in both series are furnished with abstracts in Danish and Greenlandic. Maps at various scales accompany many of these publications. The Bulletin series, started in 1948, contains memoir studies that mostly represent comprehensive and exhaustive reporting of a set subject; the Rapport series, initiated 15 years later, is designed for preliminary presentations of results as well as for shorter current research papers. Thus the series covers a wide range of scientific depth and emphasis from general multidisciplinary expedition reports to specialised and detailed scientific articles.

The annual Report of Activities is published in the Rapport series.

\section{Open File Series}

This series contains unedited reports and maps produced in limited numbers. It is a key to the field of economic mineral deposits, containing reports based on data collected by GGU as well as the commercial sector (Schønwandt, 1993). Reports on petroleum geology and hydrology also appear in the series.

Formally introduced in 1989 to enable preliminary field and analytical data to be made quickly available to the public, the numbered series was expanded to include a selection of reports on economic geology issued in the previous three years. By the end of 1993 some 50 titles made up the series. 


\section{Glaciological and hydrological Series}

Prior to the launching of the Open File Series certain glaciological and hydrological reports relevant to the assessment of hydropower potential were issued as a separate series, viz. Gletscher-hydrologiske Meddelelser. The series, initiated in 1981, contains titles in both English and Danish. The series was discontinued in 1987 when such glaciological and hydrological reports were incorporated into the Open File Series.

\section{Geology of Greenland}

This comprehensive 600 page volume, which has been a standard reference work on the regional geology of Greenland, was published nearly two decades ago (Escher \& Watt, 1976). An up-dated follow-up book is in preparation and aimed for release to mark GGU's 50th year anniversary in 1996.

\section{National map sheet coverage}

The standard national map sheets are produced at scales 1:100 000 and 1:500 000 for geological maps and at acale 1:500 000 (and occasionally 1:1000 000) for Quaternary maps. These coloured, contoured maps are issued as separate sheets, or together with a map sheet description where available. Ten sheets of the 14-sheet geological series at 1:500 000 have been released, while at the end of 1993, fifty 1:100 000 sheets had been published. Publication of the Quaternary maps has been more sporadic (see 'Publications of the Survey' at the end of this Report of Activities for details).

\section{Maps of Greenland at 1:2 500000}

Two general maps at wall chart size (scale 1:2 500 000) covering the whole of Greenland have been published: a Tectonic/geological map (1970) and a Quaternary map (1971). A completely revised edition of the bedrock map, that includes the geology of the continental margins and immediate offshore, as well as the adjacent part of Canada north of $77^{\circ} \mathrm{N}$, is scheduled for release in 1994 (Escher \& Pulvertaft, in press).

\section{Aeromagnetic anomaly maps}

Map sheets showing aeromagnetic anomalies cover both onshore and offshore areas. Much of East Greenland is covered by four sheets at a scale of 1:1000 000 while a single sheet at 1:500 000 has been released from West Greenland (see 'Publications of the Survey' at the end of this Report of Activities for details). The processing, analysis and compilation techniques used in the compilation of these maps are described in separate reports (e.g. Thorning, 1982, 1984). Data used in the compilation of these maps are available from GGU in digital form (see later under 'digital data').

\section{Thematic Map Series}

As a step in mineral resource evaluation and as a consequence of the advancement of computerised mapping and data presentation techniques, a thematic map series was launched in 1990 (Fig. 1). The series is designed in the form of loose-leaved volumes to enable the insertion of up-dated maps as new data become available. The first volume covers the Nuuk - Maniitsoq region of southern West Greenland $\left(63^{\circ}-66^{\circ} \mathrm{N}\right)$ (Steenfelt et al., 1990). It comprises 57 maps at scale 1:1000 000 showing geological, geophysical and geochemical data as well as mineral occurrences. The second volume deals with South Greenland (Thorning et al., in press; see Fig. 1) and the following volumes will cover West Greenland up to $71^{\circ} \mathrm{N}$ (north of Disko - Nuussuaq, Fig. 2). (See also under 'digital data').

\section{Maps outside standard series}

Included here is a wide range of special maps at various scales: land and sea-floor geology, geochemistry, bathymetry, topography, glaciology, hydrology, seismicity, off-

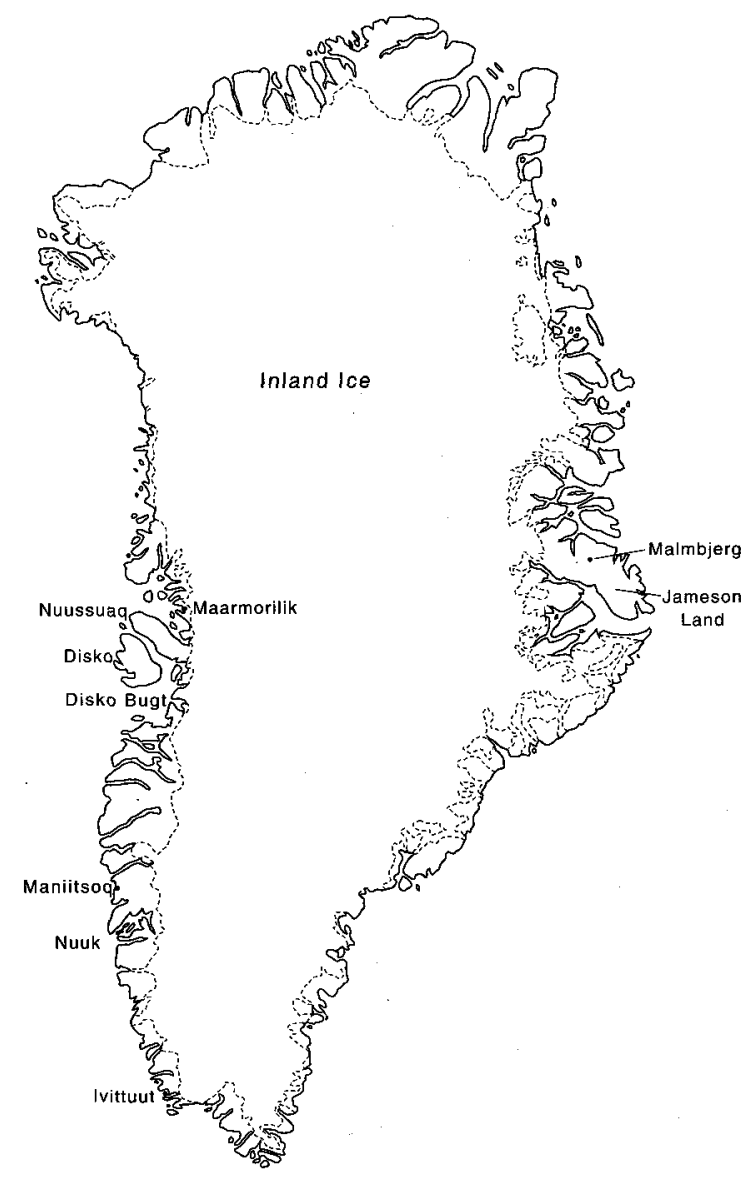

Fig. 2. Map showing localities referred to in connection with GGU's publication and data service. 
shore seismo-stratigraphy, and aeromagnetic and aeroradiometric anomalies. Many maps have been issued to accompany bulletins and reports, others are available as separate sheets. Examples of the latter category are the map series comprising 86 bathymetric maps offshore West Greenland issued in 1974 and 26 geochemical maps over South Greenland printed in 1982.

\section{Publication packages}

This service, formalised this year, is designed to provide sets of GGU publications to cover regional or disciplinary geology of a particular province or target area, or of a specific subject or economic commodity. Packages are customer-requested.

\section{Digital data}

A wide variety of data is now available from GGU in digital form. This includes the data used in the production of Survey maps as well as a range of raw and processed data stemming from GGU's own work programmes and from industry and other sources. Costs for copies of digital data vary according to nature and derivation. Some data sets, such as those behind Survey publications, can be purchased at prices corresponding essentially to the cost of processing and handling.

GGU can advise on the availability and acquisition of digital data and help with information on the existence of data from other surveys not held in-house, and on its availability or confidentiality.

\section{Published map data}

Digital data of this category include many of the parameters behind the released thematic, aeromagnetic and geochemical maps, as well as some geological maps. In addition the photogrammetrical digital data used in the construction of topographical maps, both published items and those used for field work and geological compilations, can also be made available.

\section{Mineralisation Data Bank}

GREENMIN (Greenland Mineralisation Data Bank) is a computerised database designed to incorporate all known economic mineral localities in Greenland. It provides data in a systematic and easily manageable form for easy use by industry and for GGU's own resource evaluation programmes and research (see Lind et al., this report). Mineral occurrence maps showing code numbers identifying localities from which data are available, are published in the Open File and Thematic Map Series.

\section{Seismic data archive}

This archive of reflection seismic profiles contains more than $55000 \mathrm{~km}$ data from West Greenland and c. $29500 \mathrm{~km}$ data from East Greenland, of which $1800 \mathrm{~km}$ are onshore data from Jameson Land (Fig. 2). Film and paper copies of released GGU and industry seismic lines are available.

Navigation data, acquisition and processing parameters, and information about availability of the seismic data are filed in a database. Processed seismic data from many surveys have been loaded onto a Landmark 2D workstation for interpretation purposes. Interpreted seismic sections and navigation data can be processed by other software to create various types of maps.

Original field or processing tapes are not stored by GGU, but copies of processing tapes from most surveys are stored for in-house use. Tapes from GGU and other surveys are stored by tape storage companies in Great Britain and the USA.

\section{Well log data}

Copies of well log data including those from the five wells drilled offshore West Greenland in 1976 and 1977 are stored together with the seismic data described above. The most important logs from the five wells have been digitised and compiled using Sierra Geophysics Inc. software and can thus be obtained in digital form. All well information presently held by GGU has passed out of confidentiality and can be inspected.

\section{Petroleum data}

Source rock and reservoir analytical data, both the Survey's own data and that acquired and delivered by industry under concessionary terms, are stored in a database.

\section{Newsletters, unpublished reports and maps}

\section{GHEXIS and MINEX}

GHEXIS (Greenland Hydrocarbon Exploration Information Service) and MINEX (Greenland Mineral Exploration Newsletter) are biannual newsletters designed to provide up-to-date geological, expeditionary and legislatory information to the oil and mining industries. Legislatory information included is released in conjunction with the Mineral Resources Administration for Greenland (MRA). GHEXIS was launched in 1990, MINEX in 1992. The two newsletters are available from GGU free of charge (Fig. 3).

\section{Reports and diaries}

GGU's archive contains hundreds of unpublished geological reports and field notes or diaries from all regions of Greenland dating back to the earliest GGU expeditions in the late 1940s. This archive also contains degree theses from Danish and foreign universities or geological institutes based on GGU instigated work. 


\section{OFFSHORE WEST GREENLAND NON-EXCLUSIVE SEISMIC DATA}

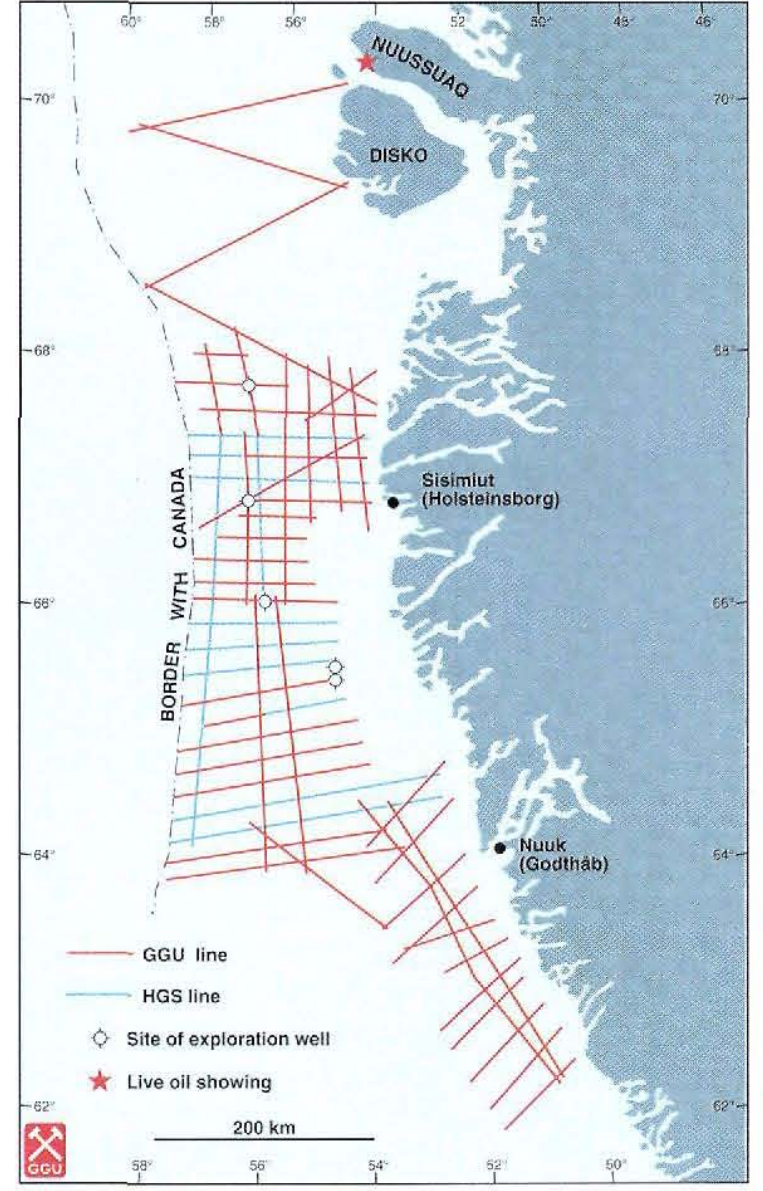

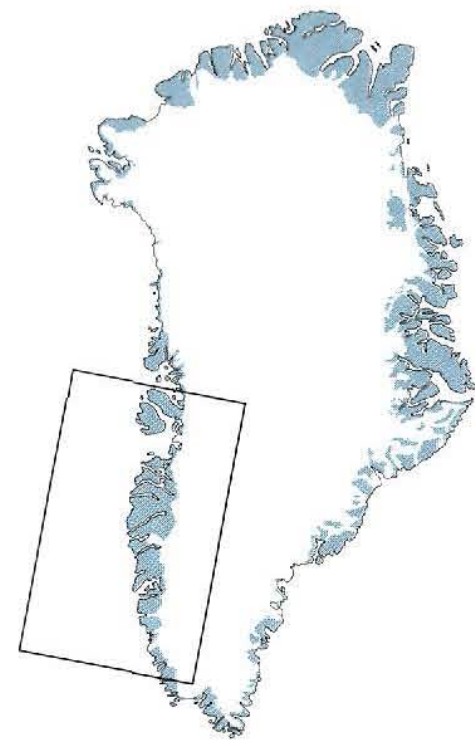

$8553 \mathrm{~km}$ data provide new, integrated regional grid.

- Data acquired 1990-1992 using tuned airgun arrays; recording to $8 \mathrm{~s}$ at $2 \mathrm{~ms}$ intervals on $3000 \mathrm{~m}$ cable with 120 channels.

- Processing with special emphasis on removal of strong seabed multiples and migration of the 60 fold stack.

\section{GEOLOGICAL SURVEY} OF GREENLAND

Fig. 3. Example of GHEXIS information service: front page of pamphlet on new scismic data available to industry. 


\section{Industry report library}

Commercial companies operating in Greenland are obliged to submit reports on their exploration and exploitation activities to the Danish and Greenlandic authorities. These reports are housed at GGU in Copenhagen. Each report is confidential for a given period determined by the concessionary terms.

At present more than 2000 reports make up the publically accessible part of the library. The main sections comprise 1100 reports pertaining to mineral occurrences, their exploration and exploitation, and approximately 750 items dealing with hydrocarbon-related geological and geophysical work. The remainder deal with exploration and drilling for coal, ornamental stone, etc.

The list of these reports is expanding as material confidentiality expires. The mineral and hydrocarbon reports are registered in databases with search possibilities using a variety of entry criteria. A fee is charged for executing extensive searches. Copies of released reports are available on normal terms; report material that is capable of being satisfactorily reproduced will be photocopied. Other reproduction techniques can be employed at extra cost. Microfiche copies of the released reports from mining companies are available for inspection, both in Copenhagen and Nuuk, Greenland.

\section{Map, photo and satellite image archive}

A large number of unpublished geological maps, annotated aerial photographs and satellite images from all regions of Greenland make up the archive. The collection includes over 5000 detailed field maps and aerial photographs used in the compilation of the national map sheets and other published maps. The satellite material includes a collection of Landsat and NOAA images filed in a database.

\section{Topographic and photogeological maps}

The national topographic map coverage of Greenland is produced by Kort- og Matrikelstyrelsen (National Survey and Cadastre, Denmark; previously Geodetic Institute). However, topographic map sheets covering about 25 per cent of Greenland's ice-free land (c. $\left.100000 \mathrm{~km}^{2}\right)$ have been produced in GGU's photogeological laboratory (Hougaard et al., 1991). These are predominantly from North, North-East and central West Greenland and are mainly at scale 1:100 000 .

The maps are designed for use in the Survey's own field programmes and for the most part have been compiled concurrently with geological interpretation of aerial photographs. However, they can be made available to commercial enterprises (see below, 'Consultancy and laboratory services').

\section{Rock sample archives}

Rock samples stored at GGU are derived from the Survey's own collecting as well as material delivered by industry. Rock from all regions of Greenland is represented in the archives, including some material from offshore wells. All the material described below can be inspected on request, and in most cases material not being worked on can be made available for renewed investigation. Some of the samples are registered in databases and can be retrieved using a range of search criteria.

\section{Standard rock collection}

Included here are all rock and surficial material collected during GGU's own surface investigations. Out of more than 300000 numbers registered, some 100000 representative samples, 12000 thin sections and 2500 polished sections make up the consultative part of the collection.

\section{Mineral industry sample archive}

Rock samples derived from commercial mineral exploration and mining enterprises make up this archive. It comprises about 25000 samples with accompanying thin sections and polished sections. The material stems from mineral prospects and exploited deposits in a number of different areas of Greenland (including areas mentioned below, under 'drill core library').

\section{Drill core library}

Diamond drill cores from a number of prospected and mined deposits in South-West, West and East Greenland, comprise the library that was opened for consultation in 1989. The present status is nearly $75000 \mathrm{~m}$ of core from 1050 drill holes (Schønwandt, 1991). Nearly two thirds of the total core length comes from three areas: the lead-zinc deposits in the Maarmorilik area $\left(71^{\circ} \mathrm{N}\right)$, the cryolite deposit at Ivittuut $\left(61^{\circ} 30^{\prime} \mathrm{N}\right)$ - both these areas in West Greenland have seen mining operations - and the unexploited porphyry-molybdenum occurrence at Malmbjerg $\left(72^{\circ} \mathrm{N}\right)$ in East Greenland (see Fig. 2).

\section{Hydrocarbon sample and core archive}

Stored in this archive are all samples and shallow drill cores collected for hydrocarbon exploration purposes by GGU, as well as representative cuttings from commercial drilling. A total of $3261 \mathrm{~m}$ shallow cores have been retrieved by GGU from 68 well sites, viz. $807 \mathrm{~m}$ from 12 sites in West Greenland, $2109 \mathrm{~m}$ from 43 sites in East Greenland and $345 \mathrm{~m}$ from 13 sites in North Greenland. Cuttings from the five wells drilled offshore West Greenland in 1976-1977 are contained in the archive and can be inspected. 


\section{Bibliographical and special services}

\section{Greenland bibliography database}

GGU's bibliographic facilities include a computerised geological bibliography containing over 7250 references pertaining to Greenland geoscience. The bibliography covers a full range of geological topics including, for example, such subjects as physical geography, pedology and meteorites. Searches can be made according to topic, author, region and year.

\section{Special data packages}

GGU prepares special data packages of particular relevance for the commercial sector. The most recent is the 'Offshore West Greenland - Exploration Information' package offered in connection with the recent licensing round for hydrocarbons in the offshore region between $62^{\circ}$ and $66^{\circ} \mathrm{N}$ (Christiansen et al., 1993). The package contains a range of published and unpublished material including catalogues of all seismic and well log data.

Special data packages are offered at cost of production unless unreleased non-exclusive data are included, in which case purchase cost will be in line with commercial prices.

\section{Consultancy and laboratory services}

A number of special services can be individually arranged, but are dependent on work schedules and facility capacity at GGU. These include consultancy dealing with both practical and scientific matters as well as the hiring of laboratory facilities: for example, preparation of base maps from aerial photographs, production of petrographic thin sections and chemical analyses.

\section{Final comment}

GGU strives to spur exploration activity in Greenland by gathering, processing, cataloguing and communicating relevant geological data for industry research development. In order to achieve this the Survey combines modern research tools such as computerised analysis and numerical modelling with a solid scientific background and expertise in field geology. The publication and data service now available reflects this approach.

\section{References}

Brett, C. P. \& Zarudzki, E. F. K. 1979: Project Westmar - a shallow marine geophysical survey on the West Greenland continental shelf. Rapp. Grønlands geol. Unders. 87, 29 pp.
Christiansen, F. G., Marcussen, C. \& Pulvertaft, T. C. R. 1993: Petroleum-geological activities in 1992: preparation and support for licensing rounds offshore West Greenland. Rapp. Grønlands geol. Unders. 159, 38-42.

Dawes, P. R. \& Schønwandt, H. K. 1992: Geological setting of Precambrian supracrustal belts: a fundamental part of mineral resource evaluation in Greenland. Rapp. Grønlands geol. Unders. 155, 19-23.

Denham, L. R. 1974: Offshore geology of northern West Greenland $\left(69^{\circ}\right.$ to $\left.75^{\circ} \mathrm{N}\right)$. Rapp. Gronlands geol. Unders. 63, $24 \mathrm{pp}$.

Escher, A. \& Watt, W. S. (ed.) 1976: Geology of Greenland, 603 pp. Copenhagen: Geol. Surv. Greenland.

Escher, J. C. \& Pulvertaft, T. C. R. in press: Geological map of Greenland, 1:2 500 000. Copenhagen: Geol. Surv. Greenland.

Ghisler, M. 1990: Towards a new decade in Greenland geology. Review of the Survey's activities in 1989. Rapp. Gronlands geol. Unders. 148, 7 only.

Grønlands Baseselskab 1991: Geodata: Geological information. Trade and Industry in Greenland 2, 20 pp. Copenhagen: Grønlands Baseselskab A/S.

Hougaard, G., Jepsen, H. F. \& Neve, J. K. 1991: GGU's photogeological laboratory: aerial photogrammetry - a valuable geological mapping tool in Greenland. Rapp. Grønlands geol. Unders. 152, 32-35.

Roksandić, M. M. 1979: Geology of the continental shelf off West Greenland between $61^{\circ} 15^{\prime} \mathrm{N}$ and $64^{\circ} 00^{\prime} \mathrm{N}$ : an interpretation of sparker seismic and echo sounder data. Rapp. Gronlands geol. Unders. 92, $15 \mathrm{pp}$.

Schønwandt, H. K. 1991: Economic mineral resources: activities in 1990. Rapp. Grønlands geol. Unders. 152, 41-46.

Schønwandt, H. K. 1993: GGU Open File Series: a review of reports related to Greenland mineral exploration. Rapp. Grфnlands geol. Unders. 159, 22-24.

Steenfelt, A., Thorning, L. \& Tukiainen, T. 1990: Regional compilations of geoscience data from the Nuuk - Maniitsoq area southern West Greenland. Thematic Map Ser. Grønlands geol. Unders. 90/1, 57 maps, 9 pp.

Stemmerik, L., Pulvertaft, T. C. R. \& Larsen, H. C. 1990: Current activities in the field of hydrocarbon geology. Rapp. Gronlands geol. Unders. 148, 24-29.

Thorning, L. 1982: Processing and interpretation of aeromagnetic data in The Geological Survey of Greenland. Rapp. Gronlands geol. Unders. 114, 42 pp.

Thorning, L. 1984: Aeromagnetic maps of parts of southern and central West Greenland: acquisition, compilation and general analysis of data. Rapp. Gronlands geol. Unders. 122, $36 \mathrm{pp}$.

Thorning, L., Tukiainen, T. \& Steenfelt, A. in press: Regional compilations of geoscience data from the Kap Farvel - Ivittuut region, South Greenland. Thematic Map Ser. Gronlands geol. Unders. 94/1

Trettin, H. P. 1991 [issued 1992] (ed.): Geology of the Innuitian orogen and arctic platform of Canada and Greenland. $569 \mathrm{pp}$, 9 maps. Geology of Canada 3 (also Géologie du Canada 3 and The Geology of North America, Vol. E). Ottawa: Geological Survey of Canada.

P. R. D., Geological Survey of Greenland, Copenhagen 